\title{
The Research of Initial Public Offering Audit Risk Management
}

\author{
Lixing Wang \\ School of Management, Jinan University, Guangzhou, China \\ Email: lovestarly@163.com
}

Received 7 October 2015; accepted 24 October 2015; published 27 October 2015

Copyright (C) 2015 by author and Scientific Research Publishing Inc.

This work is licensed under the Creative Commons Attribution International License (CC BY). http://creativecommons.org/licenses/by/4.0/

c) (i) Open Access

\begin{abstract}
IPO fraud has been a hot issue in academic research recently. The false statement behaviors of enterprises severely affect the healthy development of capital market, harm the interests of investors, and thus cause a widespread concern in the community. In these cases, there are also impacts on the accounting firms' economic and reputation in varying degree. The effective management of audit risks can reduce the loss, timely correct the possible audit risks, and improve audit quality and professional image of CPA. This paper mainly researches how to supervise and control the audit risks in the IPO audit project.
\end{abstract}

\section{Keywords}

Initial Public Offering, Audit Risk, Certified Public Accountant

\section{Introduction}

In recent years, IPO frauds frequently occur in capital market in china, such as Edmond Health Division, green earth, and the new earth. CPA suffered severe tests. Regardless of whether the punishment is serious, the reputation of audit firms is influenced by a certain degree. The management of audit risks is particularly important with audit risks virtually increasing.

In the fraud case that Hontex International Holdings Company was fraud in IPO, KPMG failed auditing for its IPO. The auditors' behavior suspected of taking bribes, but KPMG was not punished by the court or the Securities \& Futures Commission. Instead, KPMG gained the support and respect from public, considered a great help to restoring the investors' losses.

Similar events at different processing result reflected the effectiveness of different management of audit risks. The effective management of audit risks will manage the audit risks actively in accordance with the law and the reason how audit risks happen. Then it can reduce the loss audit risks, correct and remedy the possibility of audit 
risk timely. At last it improves the quality of auditing and CPA's professional image. The industry of certified public accountants in our country is in the initial stage of development; the awareness of risks is relatively weak, and it also has a limited ability to bear risks. What the management of audit risks is will directly affect this industry's survival and development.

The following content is divided into four parts. This paper firstly combines the research literatures about IPO audit risk and states the evolution of the audit risk model. Then the main IPO audit risks are analyzed in this paper. The third part is some management suggestions and requests that are given according to main IPO audit risks. The last part is conclusion.

\section{Literature Review}

Abroad study of audit risk started earlier, which has the comparatively mature theory. Montgomery audit learn was the beginning of the management of audit risks, which associated the audit risks and the audit implementation programs for the first time. Then the research on management measures of audit risks and improving audit methods. In the 1970s, the audit risk model is gradually applied in the audit practice. The auditing standards committee proposed the inherent risk, control risk and check risk in 1983, which constitute the traditional audit risk model: audit risk $=$ inherent risk $*$ control risk*check risk. International audit and verification standards committee in October 2003 enacted the new audit risk criteria specified the audit risk mainly included the material misstatement risk and check risk. Material misstatement risk is composed of inherent risk and control risk [1].

The practice and academic research of audit risk had an auditing recovery since 1980 the system of certified public accountants was recovered in china. From paying no attention to audit risks because of economic system to gradually researching the audit risks, the scholars made in-depth analysis and research on the causes of audit risk, audit risk model, the audit risk control and prevention, and so on, forming some relatively mature theory of audit risks [2]. In audit that is the teaching material of Shanghai University of Finance and Economics, editor in chief Zhou Qinye etc. Put forward a new audit risk model: audit risk (AR) = inherent risk (IR)*control risk (CR)*Non-sampling risk (USR)*sampling risk (SR), which is modified version of the model of D. H. Roberts' audit risk model. It has won the acceptance of the audit in our country in a certain extent. Lv Bo (2005) put the random disturbance factor into the audit risk model, building a new audit risk model: audit risk $=$ inherent risk*control risk*check risk + random perturbation terms [3]. In discuss about the reconstruction of the concept of audit risk and audit risk model, Zhou Jiacai (2002) defined audit risk model as: audit risk = inherent risk*control risk*detection risk*litigation risk [4]. In 2006, the institute of certified public accountants issued the certified public accountant professional standards in our country assimilation to international auditing standards in the financial statements audit goal and general principle, adopting the modern audit risk model: audit risk = risk of material misstatement*check risk.

We can see from the above, the international audit risk model in the process of perfecting, and auditing standards in China due to the late start, is at a stage of convergence with the international standards.

\section{The Causes of IPO Audit Risk}

Both the objective reasons such as the complexity of the audit law, the complexity of audit object, the universality of the audit contents, etc., and the subjective reason of the accounting firms can lead to IPO audit risk. The discussion and analysis of this article is risk control in the process of IPO audit, so there is no analysis of the objective reasons that IPO audit risk but focused on main body, analyzing the causes of IPO audit risk from the angle of certified public accountants.

\subsection{Employees' Competence}

Accounting firms usually regard the IPO audit services business as the key to treat and handle, which will draw the most capable of certified public accountant in the business of IPO audit business. But because of the complexity of the IPO auditing, the diversity of accounting information, the diversity and complexity of the types of the economic business of listed companies, the demand for certified public accountants is higher. IPO audit involves not only the traditional financial statements audit, but also the table audit extreme purpose, such as the feasibility of the proposed investment programs of listed companies according to professional judgment, the 
evaluation of the internal control system and the operation effect, the continuing operations capability. But the existing registered accountants are able to do the traditional reconciliation, but for the other audit, they lack of experience. When they have a problem, the ability to analyze and solve problems is relatively insufficient, unqualified for IPO audit requirements.

\subsection{Lag of IPO Audit Methods}

The scale of the modern enterprise is more and more big, the scope of business is more and more widely, from the consideration on the economy and efficiency of the audit, it is impossible for auditor to conduct a comprehensive audit, but it is widely to use the sampling techniques and methods in the audit process accompany with the sampling risk and error inevitably. It is the result of the sampling audit to infer the overall audit results. This link is very easy to cause the IPO audit risk [5]. The actual situation of the enterprise are not identical, and certified public accountants sample according to the experience of the sampling, so the extracting samples may not represent the actual situation of the audit's overall, and accountants according to the deviation from the actual situation of the sampling results for inference, probably wrong audit conclusion, the resulting audit risk.

\subsection{Audit Quality Control System}

Audit quality control is an important part of accounting firm management activity and the core of certified public accountants internal control. The international auditing practices committee and the national institute of certified public accountants pay high attention to the audit quality control system, and introduced the corresponding code. On January 1, 1997, Chinese certified public accountants quality control basic principle was approved by the ministry of finance and came into effect; On February 15, 2006, the ministry of finance has issued certified public accountant professional standards of China, including two project about audit quality control; In 2010 the ministry of finance promulgated certified public accountants auditing standards also including two project about audit quality control. This suggests that audit quality control has given rise to a high degree of policymakers' or regulators' attention. In practice, the accounting firm in our country is still in the stage of development. Quite a number of accounting firms did not establish and perfect quality control system in accordance with the provisions of laws and regulations even making quality control system stay on paper. Some quality control measures are still stay in the audit work papers review level. In the actual process of the implementation of quality control, it becomes a mere formality, and there is no substantial content. It does not give full play to the audit quality control in the most important three-step checking system. This will cause the audit risk in the process of IPO.

\section{Coping Strategies}

\subsection{Improve the Quality of the Certified Public Accountants}

First of all, on the choice of IPO audit personnel should pay attention to comprehensive quality and professional ability. IP0 audit business requires extremely high personnel quality. To choose the personnel engaged in IP0 audit we should consider not only the experienced personnel but also whether a personnel with multi-disciplinary background, such as computers, mathematics, etc. So you can play to the advantages of multiple disciplines, collaboration, and improve the efficiency of the audit, control audit risk.

Second, strengthening the training of existing staffs is important. To most accounting firms, when the certified public accountants join accounting firms, they are bogged down in the multifarious actual business. Working overtime becomes the norm. In this case, they may not have time and energy to study. The resulting knowledge structure aging, the knowledge they have may not keep pace with the development of audit theory and audit practice needs. When the business is relatively small, it is required to strengthen the internal training of personnel. On one hand they can invite experienced certified public accountants within the scope of their accounting firms; on the other hand they can use the resources of colleges and universities. The professors engaged in theoretical research, keeping up with the latest development of auditing theory, so they can provide trainees the most useful, efficient knowledge in the short term to improve the knowledge structure of certified public accountants.

Finally, give full play to the role of the experts. The scope of IP0 audit business is very broad. For the knowledge structure of certified public accountants cannot cover all the knowledge, it is need to give full play to the 
role of the experts. They are mainly divided into internal and external experts. For the internal experienced certified public accountants, on the one hand they can be involved in the audit business IP0; on the other hand they can take advantage of its abundant experience, making its internal training for auditors [6]. In addition to the accounting firm's internal experts, we should also consider making full use of the power of outside experts. Outside experts mainly come from professional institutions and universities out of accounting firms. External professional institutions with their independence and professionalism not only can provide real, high quality management information, but also can provide professional analysis method and reasonable suggestions. All of these can help to accurately assess the certified public accountants enterprise risk management strategy. College teachers have rich theoretical knowledge and scientific research ability. If the scientific research results such as specific audit process can be applied to public accountants for certified public accountants audit risk control, it can play a big role.

\subsection{Implement Modern Risk-Oriented Audit Model}

Modern risk-oriented auditing is the latest audit model based on the concept of risk control of the public accounting firm. The fundamental goal of risk-oriented audit model is to reduce the audit risk of certified public accountants, controlling the risk of accounting firm at an acceptable level. Risk-oriented audit attaches great importance to the audit strategy choice, which both pay attention to reducing audit risk and saving audit cost. It can be said that modern risk-oriented audit is to achieve the goal what is controlling risk from the date of birth.

Although China already introduced risk-oriented audit model, and quite a part of the accounting firms are carrying out this model gradually, but as a result of the implementation of modern risk-oriented audit the audit cost will increase, and the quality requirements for personnel will be higher. Carrying out this model faces some obstacles. But the strength of the risk-oriented audit model is obvious. Modern risk-oriented audit model requires in-depth grasp and understands the situation of the enterprise management, then evaluate the enterprise business risk. It can effectively reduce the audit risk of certified public accountants. Risk-oriented audit has a theoretical and practical significance for improving the auditing efficiency, controlling the auditing risk and as assuring the auditing quality [7]. Modern risk oriented audit can not only improve the efficiency of the audit of financial statements compliance to express an opinion and the fair sex, but also prove that whether the financial statements' fraud, especially management fraud. Modern risk-oriented audit analyze the risk of material misstatement systematically with the new audit model, and determine the corresponding audit strategy. Risk assessment will be closely integrated with the audit procedures. And on this basis deploy more audit resources to the high risk areas, which can effectively increases the audit quality and efficiency. But in our country, risk-oriented audit model extended to all the engagement face greater obstacles in the short term, so we can firstly consider the promotion in the IP0 engagement. On the one hand, this will effectively reduce the IP0 audit risk; on the other hand this can also help for the further application of audit mode.

\subsection{Establish and Improve the Internal Quality Control System}

One of the important contents of the audit risk control is to improve the quality of internal control. The improvement of accounting firms' internal quality control will reduce the IP0 audit risk. The establishment and perfection of the internal quality control system is a comprehensive, systematic and complex project, which need to pay attention to each link of the process of IP0 audit. They should ensure the quality of each stage of the audit, from undertaking projects to developing audit plans, from the three-step checking control, to risk control process of report and so on. The priority in establishing internal quality control system is the establishment of the internal quality control system.

\subsubsection{Establish and Improve the Audit Quality Standards}

Audit quality standards is audit quality control basis and code of conduct auditing business, which is a measure of audit quality, also is the basis of the implementation of audit quality control. Accounting firms shall establish audit quality standards suitable for the actual situation, according to the relevant laws, regulations and industry standards, combined with the actual situation of the public accounting firm. The audit quality standards should maintain its relative stability and continuity, but also adjust constantly along with the change of the laws, regulations and audit environment. 


\subsubsection{Establish and Improve the Professional Guarantee System}

Professional guarantee system requires a set of standardized, institutionalized, strong operability procedures or work processes in the process of implementing IP0 audit business. For instance, to the whole process of engagement, the audit business process can be broken down into preparation, implementation, and issuing the report. The audit quality of each stage will affect the final audit conclusion. Public accounting firms should formulate specific operation standard and working process according to the characteristics of each stage of the specific business and risk control requirements, which is an important institutional guarantee of IP0 audit risk control.

\subsubsection{Establish and Improve the Triple Check System}

Review system is necessary to reduce IPO audit risk and improve audit quality guarantee. Although there is no mandatory that accounting firm set up a review system in Chinese certified public accountants quality control basic principle, in fact, most of the accounting firms have established the triple check system, which plays an important role in improving audit quality.

\subsubsection{Establish and Improve the System of Examination}

Accounting firms should check and evaluate the project team for audit quality through scientific and reasonable evaluation index, combined with the institute of risk control target, according to the standard of audit quality. According to the result of evaluation determine the compensation level and position promotion, making clearly rewards and punishment. For not compliance auditing procedures, or auditors failed to fulfill in the process of work, the accounting firms will give punishment. Combine IP0 audit risk with personal assessment of rewards and punishments, which will strengthen the consciousness of audit risk.

\section{Conclusion}

IPO audit has become an important part of the accounting firm business. Along with our country capital market to mature and grow, it will be an important content to the practice of certified public accountants. Now, IPO audit risk is the focus of theoretical and practical circles. On the basis of this, this paper analyzes the reason of IPO audit risk and how to control the IPO audit risk. But the defect of this paper is lack of systematic and empirical quantitative research.

\section{References}

[1] Franeis, W. (2005) Audit Risk in a Brave New World. Commercial Accounting.

[2] Zhang, C.T. (2001) The Concept of Audit Risk. The Audit Research, 2, 39-41.

[3] Lv, B. (2002) Audit Theory Research under the Information Technology Environment. The Chinese Certified Public Accountant.

[4] Zhou, J.C. (2002) Try to Talk about the Reconstruction of the Concept of Audit Risk and Audit Risk Model. Studies of Finance and Economics.

[5] Dye, R.A. (1993) Auditing Standards, Legal Liability, and Auditor Wealth. Journal of Political Economy, 101, 887914. http://dx.doi.org/10.1086/261908

[6] Lindborg, H. (2007) Adapt to Today Risk Based Environment. Quality Progress.

[7] Le, L. (2011) Are Audit Programs Responsive to Audit Risk. University of Alberta. 